\title{
IMAGE OF SLOVAKIA IN THE CONTEXT OF EASTERN EUROPE
}

\author{
LenKa Môcová ${ }^{1}$ \\ University of Žilina (Slovakia)
}

\begin{abstract}
The paper deals with the problem of Slovak image abroad. Slovakia is a small country in terms of population and geographical size and despite its natural beauties and positive economic development it does not draw enough attention.

The paper describes two main approaches to nation branding and outlines several typical branding strategies of chosen Eastern European countries. As there is a strong correlation between the image of Slovakia and Eastern Europe, the paper also studies the common characteristics of Eastern Europe image with specific focus on its reflection in popular culture. The final part of the paper summarises basic characteristics of the image of Slovakia in foreign press and briefly presents a new Slovak branding campaign Good Idea Slovakia.
\end{abstract}

KEYWORDS: image of Slovakia, nation branding, Eastern Europe, foreign press.

JEL CODES: Z19

DOI:

\section{Introduction}

Mass media are powerful image makers and their role in creating image of a country cannot be underestimated. The image of a country is a significantly complex issue because there are numerous often unpredictable influences and variables affecting it. We could observe an explosion of nation branding theories in 1990s and their subsequent reflection in various fields, e.g., media studies, public relations, public diplomacy, sociology, cultural anthropology and others. This phenomenon can be attributed to the changing rules of international relations. As P. Van Ham (2001: 4) states, nation branding is inevitable nowadays due to these changes, there is a noticeable shift from "geopolitics and power to the power and influence of visual images".

Within our preliminary research of the problem of the image of Slovakia in the British press, significant similarities between the image of Slovakia and general perception of Eastern Europe in the so called developed world were observed. This paper applied exploratory literature review method with the aim to determine the views of several topical nation branding and media studies on the problem of image of Eastern Europe.

The post-communist countries often struggle with labels as backwardness, irrationality and underdevelopment. The images presented in movies and literature are not particularly favourable, a typical Eastern European city will probably feature endless grey concrete blocks of flats and sad, gloomy people. This poses a question: Are there any ways how we can permanently affect the image of an Eastern European country? The answer actually depends on our point of view and the depth and complexity of our thinking.

Lenka Môcová - doctor of pedagogical sciences, University of Žilina, Institute of Lifelong Learning, English for Specific Purposes

Scientific interests: journalism, discourse analysis

E-mail: lenka.mocova@uniza.sk

Tel. +421948187044 
Approaches to country branding, which also includes creating and affecting image of a country, can be basically divided into two branches: critical and market-driven. The critical approaches are concerned with ideology underlying nation or country branding, while market-driven approaches are obviously more "optimistic" and straightforward, often perceiving country branding as an advertising issue.

According to N. Kaneva (2012: 10), a representative of the critical approach, branding is a neoliberal tool that creates values by commodification of emotions. On the contrary, S. Anholt (2007:39), a marketing and branding expert, claims that the interest in nation branding is simply caused by the spread of democracy and media globalisation and believes using branding tools we are able to affect an image of a country in a positive way.

The problem also seems to be the relation of branding to the national identity. Various authors, e.g., S. Jansen, (2012: 92), understand nation branding from a neo-Marxist point of view as a manipulative and totalitarian propaganda. S. Jansen approves of spreading positive information about a country e.g. in relation to its economic growth, but also adds that it cannot mean to "fabricate a new national identity, reduce civil space to calculative space, embrace the gospel of the market or dumb down its public discourse". She seems to warn against social engineering practices.

In market-driven approaches, it is important not to confuse country image, product image and the country of origin image. Country image can be understood, according to I. Martin and S. Eroglu (1993: 60), as "a set of descriptive, inferential and informational beliefs about a country". S. Anholt (2009: 5-6) clarifies that we cannot fully apply marketing terms and standards to the image or brand of a country. Countries cannot be compared to business companies and do not really create any product in its strict sense. Life of a country is a subject to numerous events and changes and the state itself is a complex institution. Moreover, a nation brand involves relatively fixed ideas and images and it is naturally problematic to alter them as people are not prone into leaving fixed stereotypes.

\section{How can we create image of a country?}

The market-driven approaches to country branding can help us address the problem of modifying an image of a country. S. Anholt (2007), recognizes 6 aspects - indicators contributing to the country image formation. These are channels we use for communication with the outside world and employing them we can turn them into productive branding tools:

- Tourism is one of the most powerful tools especially due to the power of personal experience.

- Export brands. If the consumer is satisfied with the products, he tends to perceive the country of origin / production favourably as well and vice versa.

- Government policy, especially the ability to cope with problems e.g. the unpredictable ones such as the natural catastrophes.

- Community of traders. Here, it is considered how attractive the respective country is for potential businessmen and investors and how the foreign companies prosper there.

- Cultural exchange and export of culture. This includes the way the country is depicted in various movies and books.

- Citizens of a country. Their behaviour abroad can often substantially contribute to the country image. Among ordinary citizens, an image of a country can be supported by well-known sportsmen, artists, etc.

According to numerous branding experts, by careful consideration of all the "channels" above, efficient planning and targeted campaigns we can improve image of any country. However, the perception of other country often reflects the way we perceive our own country. The social psychology-based theories claim that we cannot perceive ourselves properly without a certain level of knowledge about and interaction with other countries (Mead, 1967; Ichheiser, 1940 in Kleppe, Mossberg, 2005). Several contemporary researchers (e.g., Phalet, Poppe, 1997; Kleppe, Mossberg 2005) propound the idea that we tend to judge other countries from the point of view of our own interests. They also suggest that the stereotypical perception of other nation or a country is inversely proportional to the information and knowledge about the given country or a nation. 
The study of I. Kleppe and L. Mossberg (2005) also argues that the country image shows unique qualities in every target country, depending on the perceived importance of the other country. That is why we must be careful with applying so called generic images of countries. The perception of a country might be influenced by possible historical ties between countries, especially when there is a common historical background.

\section{Wild and backward? Problematic image of Eastern Europe}

The historical and socio-cultural development of the countries of Eastern Europe show many significant similarities. Their present image is thus deeply rooted in some persistent historical stereotypes. Here, it is interesting to notice that the term Eastern Europe is often more cultural than geographical and seems to refer to the former Ostblock countries.

According to J. Rupnik (1996 in Kaneva, 2012: 62), one of most typical characteristics of the development in Eastern Europe after the fall of communism was a sudden growth of nationalism caused by several factors, namely the end of the Cold War and related geopolitical transformations, ideological vacuum after the fall of the communist regime and the related economic transformation. L. Kulcsár and Y. Yum (2012: 207) seem to agree claiming that "the context of nation branding in Eastern Europe is different from that of the West, because of the heightened sensitivity about national identity in the region, as well as unique political economy of nation branding“".

I. Znepolski (1997: 9 in Kaneva, 2012: 6) mentions a constant "state of inadequacy", present on the level of psychological and political decisions. In other words, we are not good enough yet. He attributed this to the deep personal and social instability after the fall of old, well-established structures. What is especially significant in here is the fact that this transition can form the personal and national identity. The view of I. Ditchev (2000: 93 in Kaneva, 2012: 7) seems to confirm this state when he refers to the transformation of nations from "shameful identity to desired identity".

Despite its natural beauties and rich cultural heritage, Eastern Europe has always been a politically rather unstable region. R. Saunders (2012: 55) agrees when he sees Eastern Europe as "eternal zone of conflict and mutative politics, the Other Europe served to ignite the passions and fears of Western Europeans, while invariably being characterized as inchoate and amorphous".

M. Todorova (1997) applied psychoanalytical terminology when she admitted that westerners see Eastern Europe as the Europe's quintessential Other. She also claims that Eastern Europe, especially the Balkans is often perceived as backward, barbaric and primitive.

The prevailing image of Eastern Europe is also reflected in literature, film and other fields of culture. P. Kotler and D. Gertner (2002: 251 in Saunders, 2012: 60) state that "the entertainment industry and media play a particularly important role in shaping people's perceptions of places, especially those viewed negatively". R. Saunders (2012: 63) adds that in today's world "of overstimulated, undereducated, culturally confused youth, the country's image seems to be only as good as its latest reference in popular culture".

(The objective of this paper is not to assess the image of Eastern Europe in popular culture in all its complexity but only to describe some typical stereotypes).

The Eastern Europe has been depicted as Europe's quintessential Other since WWII. The presence of humour can make these often controversial images even more powerful. Here we can notice an interesting trend of merging all the qualities of Eastern Europen countries into one strange fictitious entity (Kaneva, 2012: 50). Hence the trend of fictitious Eastern European countries, e.g. Molvania. Molvania is a surprisingly popular fictitious travel guide. It brings a mixture of various stereotypical images of Eastern Europe: heavy drinkers, ugly buildings, cruel and resilient people, boring culture. During the Cold War, communist countries were often portrayed as fictitious dictorships, named e.g., Brutopia, Latveria, Borovia, Borduria. The suffix -ia, present in the names of several Eastern European countries was applied to indicate a dictator-led country.

R. Saunders (2012: 60) provides several examples of such practice, e.g. the Spielberg's film The Terminal with Tom Hanks as Viktor Navorski, a refugee from fictitious Slavic country Krakozhia. He is depicted as naive and soft-hearted. 
Even worse, sometimes the filmmakers decide to use the real country to represent certain values and concepts, e.g., Kazakhstan in the infamous Borat: Cultural Learnings of America for Make Benefit Glorious Nation of Kazakhstan (2006). This heavily satirical film brought up many protests from country's official representatives but, paradoxically, helped to raise its brand awareness.

The horror movie Hostel by Eli Roth from 2005 was set in Slovakia. Although the main murderer there is Dutch, Slovaks there are seen as crazy maniacs. The subtext of the film narrative is the fear of unknown and primitive East. The director himself claimed that he deliberately chose Slovakia, because it is unknown: "I set the film in Slovakia because Americans don't know anything about that country <...> But you know what, at least Americans know the country now. That's a start" (PRI, 2006 in Saunders, 2012: 61).

Similar, if not more, negative images of Slovakia were conveyed by a teen comedy "Eurotrip" (2004) by Jeff Schaffer. In this road movie, a group of American tourists are travelling several European countries and by mistake they end up in Bratislava. The city is an ugly, grey haven of concrete derelict buildings and similarly looking people who would do anything for little money.

These images may seem recent but, in fact, Slovakia was negatively portrayed much earlier, e.g., in $19^{\text {th }}$ century classics - B. Stoker's Dracula (1897) where the Slovaks were described as strange, gloomy, picturesque, looking dangerous but harmless. Also, they had an infamous role in the story as they assisted the main villain vampire Count Dracula to escape and also transported his suspicious wooden boxes.

Also, the plot of A. Christie's detective classics The Secret of Chimneys (1925) is partially set in Herzoslovakia, a fictitious country that can be associated with Slovakia although located somewhere in the Balkans. The image is not flattering, e.g., the Herzoslovakians are wild, violent, act in a strange even if rather romantic way. The author clearly borrowed the name of the country to depict a barbarian, wild, unpredictable culture.

A. Bardan and A. Imre (2012: 176) noticed similar stereotypes in the episode of popular travel series No reservations by Anthony Bourdain (February 25, 2008) where Romania was once again portrayed as a "dark, mystical and mythical place". The same can be said about a Top Gear episode from November 2009, where Romania was labelled Borat country. (The Borat movie was partially shot in a Romanian gypsy settlement). Jeremy Clarkson and his team were travelling along the monumental Transfăgărășan Highway, Bucharest, a gypsy village and the holiday resort Mamaia. The way they treated the local people and their cynical remarks were considered offensive by many Romanian watchers. A. Bardan and A. Imre compare this episode to 1936 fiction The Wheel Spins by Ethel Lina White and the novel by Graham Greene Stamboul Train (1936), where the Balkans is also depicted as a dark, mythical place where anything can happen.

Sad phenomenon is the obvious sexualisation of Eastern Europe, with stereotypical image of Eastern European women as available and immoral. R. Hall (2007b in Saunders, 2012: 56) claims this image is based on typical "limber Eastern European gymnast of the 1980s". Also, Eastern Europe is unfortunately often considered a haven of pornography producers. Popular shows, e.g., the British Boozed up Brits Abroad, show local Eastern European women as sparingly dressed and promiscuous (Saunders, 2012: 56).

R. A. Hall (2007a: 6 in Saunders, 2012: 66) criticized the trend of mocking Eastern Europe when he wrote: "in this way not much has changed from Bram Stoker's time: the need to find a setting that is simultaneously exotic and yet familiar, that acts as a prop but not distraction from the underlying goal of the art form".

G. Alpion (2002: 33-34) British writer of Albanian origin, was utterly undiplomatic when he said in reaction to the use of Albania by J. K. Rowling as a resident place of Dark Lord and his followers in Harry Potter and the Chamber of Secrets - 1998, Harry Potter and the Goblet of Fire, 2000: "I do not know why of all countries, Rowling has chosen Albania as the place that harbours evil creatures. If she has done this for laugh, then it is a cheap and irresponsible laugh at the expense of a European country that has become small, "insignificant" and "voiceless", largely as a result of political witchcraft and wizardry practiced beyond its artificially drawn and imposed borders. I am inclined to believe that Rowling's choice of Albania is an indication of the intellectual arrogance and ignorance often displayed by Western authors when writing about, to borrow Edward W. Said's phrase, "lesser peoples".

Considering all the information above, we can assume that due to historical and socio-cultural reasons, Eastern Europeans display great degree of sensitivity about the way their country is portrayed in popular 
culture, especially when it is often mocked or portrayed negatively. The same question arises again - could we really affect the image of our country and if so, how?

\section{What are some Eastern European branding strategies?}

The name of some Eastern Europen coutries is a source of frequent confusion and thus a proof of their weak nation brand recognition, e.g. the often confused Slovakia and Slovenia, Latvia and Lithuania. As S. Anholt (2007) put it, Iceland and Ireland sound similar but they are not likely confused.

The Eastern European countries cannot naturally adopt a unified approach to their nation branding although many of them employ western (British, American) experts with similar approach and methodology.

As R. Saunders (2012:5) mentions, Ukraine, Moldavia and Belarus are in the first place trying to create an image of their country that would distinguish them from Russia, i.e., the common communist past.

The Baltic States have a well-developed branding strategy, e.g., Estonia being depicted as a green, almostScandinavian country. As S. Jansen (2012: 81) discusses, Estonia was one of the first post-communist countries to adopt a single branding strategy and is considered an example of successful country branding. Branding was, however, supported by the positive economic growth of the country, country's strategic location, proximity to Scandinavia and paradoxically, also the Soviet heritage - Institute of Cybernetics. The slogans of promotional campaigns reveal the message they tried to convey: Estonia, Positively Transforming. Nordic with a Twist. Ecological haven. Structured for Tourism. Quality and reliability. Flexibility and Personal Approach. Competitively Growing. E-government. Europe's Freest Market. Their recent campaigns focus on science and education.

The example of Slovenia is rather specific due to its recent history- the war in former Yugoslavia. Here, the campaigns aimed at domestic audience were also important, in order to define their national identity. As S. Volčic (2012: 148) stated, "nation branding is a part of commercial nationalism". The first marketing campaigns started in 1990s, with slogans as: A Miniature Europe, Paradise in Europe, The green piece of Europe, Green jewel of Europe, etc., but no greater success was recorded. All the marketing activities tried to emphasize the difference between Slovenia and other Balkan countries characterized by violence and instability, focusing on Habsburg heritage and depicting Slovenia as a part of mainstream European culture. The latest major campaign named I Feel SLOVEnia was released in 2007. It claimed that Slovenia is: "green, invigorates, it is elemental and is based on organic development and family"(Konečnik et al., 2009: 56 in Volčič, 2012: 152-155). S. Volčič (2012: 158) summarized that this campaign "borrowed positive, exotic elements from well-established national stereotypes and exploit them by targeting Western consumers who are searching for some kind of exotic "Other" Europe: a nearby country, but one that can be treated as an exciting, novel and diverse Other (without being much different).“

We assume that this approach could possibly work as it is based on existing stereotypes and does not challenge them but exploiting them it presents the country in a different way.

The Romanian nation branding was challenged by images of their revolution in 1989, depicting streeet riots, shot dictators, i.e. stereotypical imags of wild and violent Balkans.

As A. Bardan and A. Imre (2012: 169-187) claim, popular culture often seems to be stuck in the past where Romania was often associated with Vlad Tepes - Dracula and similar violent characters. It is thus difficult to provide potential visitors with different images because these ones meet their expectations. Dracula and Ceaucescu seem to be Romanian top attractions. The recent campaigns focus on portraying Romania as a Carpathian garden, a country for adventurous travellers. The authors surprisingly recommend the Romanian branding experts to overcome their assumed dislike for the communist past and Ceaucescu and use them as marketing symbols.

According to Laszló J. Kulcsár and Youk-ok Yum (2012: 207), in Hungarian branding campaigns we can observe the dominance of gastronomy, e.g., Pick salami, Tokay wine or Kalocsai paprika. Other key aspects of their campaigns are open borders, hospitality, spa resorts, famous Hungarians, or celebrities of Hungarian origin, e.g., Tony Curtis. Lately, Hungary tries to promote their talented people and the country as the nation of horsemen. The problem of Hungarian branding in overemphasized historical glory and superiority which is rooted in the specific character of nationalism in Eastern Europe. 
P. Surowiec (2012: 292), considers the Polish nation branding as "a part of the marketing indoctrination of a post-communist nation". The forced marketing models are based on political economy of Anglo-Saxon world. The most active agency was the British giant Saffron that tried to identify the basic attributes of Polishness. They found out that older generations are deeply pessimistic, preoccupied with history, messianic and distrustful. Besides this, they have an inferiority complex, are traditional but reveal positivist and romantic streaks. Also, they show symptoms of traumatized national consciousness. One of Saffron prominent experts - W. Olins (2004: 51 in Surowiec, 2012: 292) provides a completely different image of a young Polish generation. They seem to be different from the elderly Poles as they are cautious optimists, hold antiestablishment views, believe in market economy and find nationalism outdated. Based on this analysis, in their campaigns they try to depict Poland as work in progress, country in the state of creative tension, country of passionate, idealistic but also practical and resourceful people. Small success of these campaigns can be, according to Surowiec, explained by their ideological roots based in neoliberal ideology.

\section{Slovak branding strategies - space for innovation?}

In order to determine essential qualities of Slovak image abroad, some of its typical characteristics in mass media were studied.

According to the information available, the only one study focused on our image in British mass media was conducted by British scholar A. Burgess (1997) - Writing off Slovakia to "the East"? Examining Charges of Bias in British Press Reporting of Slovakia, 1993-1994. The author analysed the way British press reported about Slovakia in 1993-1994, i.e., after the split of Czechoslovakia. The three most frequently reported topics were the "Velvet divorce "and its consequences, then the Gabcikovo / Nagymaros dam dispute and the Hungarian minority rights. A. Burgess (1997: 679) noticed certain bias in coverage of Slovakia in British media but he concluded that this was not due to prejudice but to the fact "after the collapse of communism, a discourse developed which understood there to be East defined by proclivity for intolerance, extremism and ethnic conflict". In other words, our country was put in the box labelled Eastern Europe with all the implications. As the author further notes, concerning the Gabcikovo / Nagymaros dam controversy and the controversy over Hungarian minority rights, Slovakia came off worst.

According to K. Henderson (2002), Slovakia was virtually invisible to foreign media for a long time. Our country first hit the headlines in 1991 because of the problem of Slovak nationalism. The news focused on small-scale nationalist demonstrations in the central square in Bratislava and unfortunately, the image of Slovaks depicted as "faintly ridiculous extremists" stayed for a long time afterwards. K. Henderson also suggests that the personality of V. Mečiar contributed heavily to the bad image of Slovakia abroad. However, the image of Slovakia improved considerably in the mid - and late 1990s. The change of the government - the defeat of V. Mečiar in 1998 did not significantly improve our image, the foreign observers were rather cautious and worried about the country's future stability. K. Henderson further claims that after 2000, Slovakia is no longer invisible.

A. Školkay (2015: 225-226) in his analysis of foreign correspondents' activities in Slovakia states the most frequent topics related to Slovakia in the foreign media, namely the Roma minority and their related problems, Hungarian and partially also a Jewish minority, Slovak economic affairs and migration. He estimates the number of foreign correspondents covering Slovakia to be 20. Most of them are temporarily or permanently based in Slovakia, some of them are ethnic Slovaks and a large part of them reside in neighbouring countries.

The occurrence frequency of the topics mentioned above can be confirmed by an older analysis of A. Salner and M. Beblavý (1999) that studied the image of Slovakia in several prestigious international press media in 1993-1998.

The central problem of our image can be worded in a very simple way: they do not know much about us at all and the only information presented besides economics news are related to ethnic problems and nationalism. However, if taken positively, this also means that the blank space can be filled with positive content. 
According to the analytical report of INEKO researchers O. Gyarfášová, M. Bútora and Z. Bútorová (2012) that studies the image of Slovakia in selected foreign media, primary associations the interviewed experts had with Slovakia were: strong story of the country (our successful integration into Euro-Atlantic structures, fight against Mečiarism), proximity (propinquity) and potential. The weakness of our image is its unsatisfactory brand profile.

In 2011 Slovakia joined the Anholt-Gfk Roper Nation Index that shows how the selected countries are perceived abroad. In this rather extensive research (in 50 countries with 20,000 respondents) Slovakia ranked 38th, which only confirmed the fact that Slovakia is perceived as an unknown country with no clear associations to be connected with.

The Slovak Tourist Board (SACR) is also trying to improve our country's image. In 2011 this agency conducted an analysis of Slovak marketing strategy in the field of tourism (in 18 countries worldwide). This analysis clearly states that our most noticeable weakness is the entrepreneurial environment and the tourism infrastructure. Our brand index value is low (3.58) which indicates we are not perceived as an attractive holiday destination. It is an imperative to develop basic brand awareness in the target and potentially attractive markets. Considering our availability of financial resources the activities have to be really target-oriented communication activities.

S. Anholt (2007: 59) also studied the level of attractiveness and interest of country presentation to external audiences and he concluded that, simply said, old boring things are extremely boring, new boring things are still boring, old interesting things are fairly entertaining but new interesting things are extremely entertaining. If the presentation of our country is to be interesting and captivating it is supposed to get rid of old boring ways of presentation and focus on the innovative ones. Here, innovation is the key to successful presentation. To follow this suggestion, the Slovak branding should focus on redefining old stereotypes in presenting the country, typically including the national hero Juraj Jánošík, folklore dancing, bryndza cheese, etc., because they do not really create any special interest. Alternatively, these stereotypes deserve an unusual and original presentation.

M. Držka (2013: 187) assumes that according to the Anholt's classification the presentation of our culture and traditions will fall in the range of extremely boring to fairly entertaining and we should definitely come with new concepts and ideas. Among others, he suggests promoting our achievements in science and technology, e.g., the ESET company according to the Finnish model of promoting NOKIA in the 1990s. Our competitive identity can also be enhanced by promoting the achievements of our sportsmen, e.g., ice-hockey players.

A detailed analysis of several Slovak experts Slovakia-Country with Potential (2012) aimed to redefine our national image and identity and boldly enough, tried to capture the very essence of being Slovak, features of our national identity and mentality. If our presentation abroad is to be successful, it has to be authentic and credible. The analysis lists our cultural myths and stereotypes in a spectacular way and in the presentation of our country it proposes focusing on presenting Slovakia as:

- country that is developing rapidly and due to this it offers many opportunities;

- unique, original and a culturally genuine country;

- concentrated central Europe;

- country of innovative and progressive people that think out of the box;

- country able to adapt to harsh conditions;

- country of accumulated energy: country of creative and interesting people;

- country of positive surprises.

There have been several attempts to create a country brand and innovate our image since 1993. None of these campaigns was successful. The most recent campaign (2016) by the Slovak Ministry of Foreign and European Affairs in cooperation with the Slovak advertising agency Creative Department aims to promote Slovakia as a country of resourceful and skilled people with "good ideas" while suggesting that visiting Slovakia or invest in it is a "good idea". According to the Slovak minister of Foreign and European Affairs, Miroslav Lajčák, it has four pillars: variability, inventiveness, vitality and authenticity. Simona Bubánová (2016), head of the Creative Department agency, admits that it was inspired by "Britain is great", 2011 extensive branding campaign and estimates the first results of this campaign to become visible in three years only. 


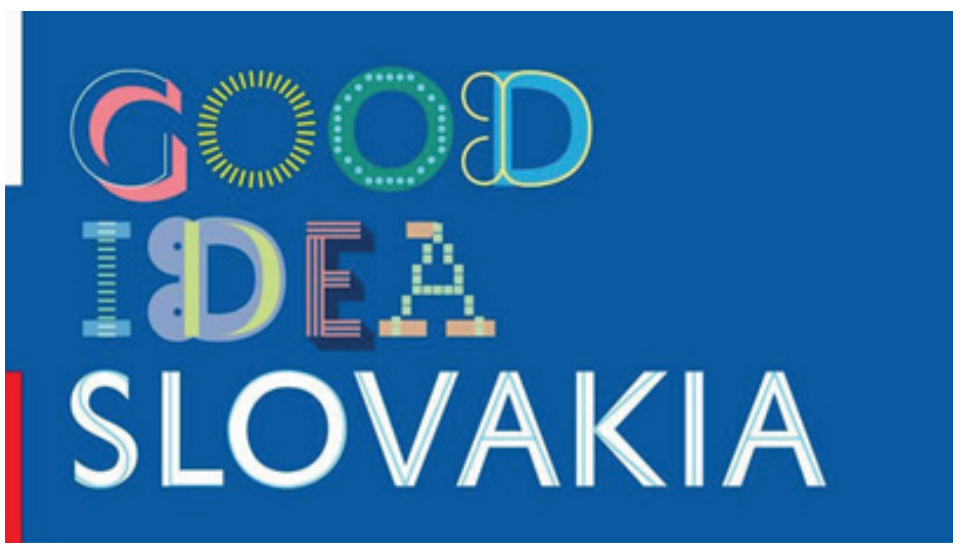

Figure 1. Logo of the branding campaign Good Idea Slovakia (colourful letters on a blue background)

\section{Conclusions}

The image of Slovakia abroad, especially in foreign media, is not particularly favourable. Our country does not possess a strong recognized brand. The foreign press coverage mostly focuses on issues related to minorities, economic problems and economic migration as these topics can be found interesting by the target foreign audience. The problems with minorities, violence and economic migration refer to the still problematic image of Eastern Europe that seems to be rooted in $19^{\text {th }}$ and early $20^{\text {th }}$ century images of wild, unpredictable and underdeveloped region.

Despite these negative images, positive marketing approach to nation branding claims we are actually able to improve the country's brand awareness and modify its image even if this is a long-term and challenging task. It undoubtedly requires dedicated work of public diplomacy, advertising and PR agencies and support of various state institutions.

The Eastern European countries seem to be occupied with redefining their national brand in order to present their countries as modern, dynamic and resourceful. I assume these campaigns are also supposed to contradict the stereotypical perception of these countries as underdeveloped and backward.

The new branding campaign Good Idea Slovakia (2016) is based on innovative ideas and presents Slovakia as a country of clever, resourceful and creative people. As it was only released a year ago, it will be interesting to observe whether this campaign has been able to modify its image to some extent.

\section{References}

Alion, G. (2002). Images of Albania and Albanians in English Literature from Edith Durham's High Albania to J. K. Rowling's Harry Potter. BESA Journal. Vol. 6, No. 2, p. 30-34.

Anholt, S. (2007). Competitive Identity. New York: Palgrave Macmillan.

Anholt, S. (2009). Places: Identity, Image and Reputation. New York: Palgrave Macmillan.

Anholt, S. (2010). Great Brand Stories: Brand America. New York: Marshall Cavendish.

Bán, A. et al. (2012). Slovensko-krajina s potenciálom. Ideový koncept prezentácie Slovenska. Ministry of Foreign and European Affairs. Available at: http://www.mzv.sk/App/wcm/media.nsf/vw_ByID/ID_BD82C7173CD03576C1257B0B0042923A_SK/\$File/Slovensko_krajina_s_potencialom_DEF.pdf [Accessed April 10, 2016].

Bardan, A., Imre, A. (2012). Vampire Branding Romania's Dark Destinations. Branding Post-Communist Nations: Marketizing National Identities in the "New Europe". London: Routledge, p. 168-192.

Bariak, L. (2016). Slovensko má nové logo: Good Idea Slovakia, 28.4.2016. Available at: https://www.aktuality.sk/ clanok/333899/slovensko-ma-nove-logo-good-idea-slovakia/

Beblavý, M., Salner, A. (1999). Tvorcovia obrazu a obraz tvorcov. Bratislava: centrum pre spoločenskú a mediálnu analýzu. 
Burgess, A. (1997). Writing off Slovakia to the "East"? Examining Charges of Bias in British Press Reporting of Slovakia, 1993-1994. Nationalities Papers, Vol. 25, No. 4, p. 659-682.

Cilauro, S., Gleisner, T., Sitch, R. (2004). Molvania, a Land Untouched by Modern Dentistry. New York: Overlook Press.

Christie, A. (2011). Tajemství Chimneys. Prague: Euromedia.

Držka, M. (2013). Nation Branding as a Presentation Tool of Slovak Republic Abroad. Aktuálne otázky svetovej ekonomiky a politiky. Available at: http://fmv.euba.sk/files/Zbornik_Smolenice_2013-1.pdf

Gyarfášová, O., Bútora, M., Bútorová, Z. (2012). Obraz Slovenska z pohl'adu zahraničia. Analytical report. Available at: https:/www.mzv.sk/App/wcm/media.nsf/vw_ByID/ID_12041E3733F74113C1257B0B004291C1_SK/\$File/ Studia_imidz_Gyarfasova_Butora_Butorova.pdf

Henderson, K. (2002). Slovakia - The Escape from Invisibility. London: Routledge.

Jansen, S. C. (2012). Redesigning a Nation Welcome to E-stonia, 2001-2018. Branding Post-Communist Nations: Marketizing National Identities in the "New Europe”. London: Routledge, p. 79-98.

Kaneva, N. (2012). Nation Branding in Post-Communist Europe. Branding Post-Communist Nations: Marketizing National Identities in the "New Europe". London: Routledge, p. 3-22.

Kleppe, I., Mosslerg, L. (2005). Country Image: A Reflection of the Significance of the Other. NA-Advances in Consumer Research, No. 32, p. 295-301.

Kulcsár, L. J., Yum, Y. (2012). One Nation, One Brand? Nation Branding and Identity Reconstruction in Post-Communist Hungary. Branding Post-Communist Nations: Marketizing National Identities in the "New Europe". London: Routledge, p. 169-193.

Martin, I., Eroglu, S. (1993). Measuring a Multi-Dimensional Construct: Country Image. Journal of Business Research, Vol. 28, No. 3, p. 191-210.

Minarechová, R. (2016). New Ideas Best Way to Promote a New Country, Slovak Spectator. 20 May 2016. Available at: https://spectator.sme.sk/c/20168095/new-ideas-best-way-to-promote-a-country.html

Môcová, L. (2015). Image of Slovakia Abroad. Transcom 2015: 11-th European Conference of Young Researchers and Scientists, June 22-24, 2015. Žilina: EDIS. University of Žilina, p. 48-52.

Phalet, K., Poppe, E. (1997). Competence and Morality Dimensions and Ethnic Stereotypes: A Study in Six-Eastern European Countries. European Journal of Social Psychology, No. 27, p. 703-723.

Saunders, R. (2012). Brand Interrupted: The Impact of Alternative Narrators on Nation Branding in the Former Second World. Branding Post-Communist Nations: Marketizing National Identities in the "New Europe". London: Routledge, p. 49-78.

Surowiec, P. (2012). Toward Corpo-Capitalism Poland as a Brand. Branding Post-Communist Nations: Marketizing National Identities in the "New Europe". London: Routledge, p. 100-124.

Školkay, A. (2015). Foreign Correspondents in Slovakia: Economy, Minorities and Sometimes Politics. Mapping Foreign Correspondence in Europe. London: Routledge.

Marketingová stratégia Slovenska Slovenskej agentúry pre cestovný ruch (2011). Available at: http://www.sacr.sk/fileadmin/user_upload/Statistiky/strategiaSACR/Marketingova_strategia_SACR_2011_-2013.pdf [Accessed April 4, 2016].

Todorova, M. (1997). Imagining the Balkans. Oxford, OUP.

Vam Ham, P. (2001). The Rise of the Brand State: The Postmodern Politics of Image and Reputation. Foreign Affairs, Vol. 80 , No. 5, p. 2-7.

Volčič, Z. (2012). You Can’t Spell Slovenia without Love... Branding Post-Communist Nations: Marketizing National Identities in the "New Europe". London: Routledge, p. 47-167. 


\section{SLOVAKIJOS IVAIZDIS RYTUEOROPOS KONTEKSTE}

LENKa Mocova

Žilinos universitetas (Slovakija)

\section{Santrauka}

Straipsnyje aptariamas Slovakijos įvaizdis užsienyje. Slovakija yra maža šalis tiek savo gyventojų skaičiumi, tiek geografiniu dydžiu. Nepaisant jos kraštovaizdžio grožio ir pozityvaus ekonominio vystymosi, ji nepritraukia pakankamai turistų. Straipsnyje aptariami du pagrindiniai nacionalinio įvaizdžio kūrimo prieigos taškai, apibrèžta keletas tipinių ịvaizdžio kūrimo strategijų, taikomų Rytų Europos šalyse. Kadangi tarp Slovakijos ir Rytų Europos ịvaizdžio yra didelè koreliacija, nagrinejjamos ịprastos „Rytų Europos charakterio savybės“, didesnị dėmesị skiriant Rytų Europos ịvaizdžiui pramogų kultūroje. Paskutinèje straipsnio dalyje apibendrinamos pagrindinès Slovakijos įvaizdžio charakteristikos užsienio spaudoje ir trumpai pristatoma nauja slovakiška ịvaizdžio strategija „Gerų idèjų Slovakija“. Slovakijos įvaizdis užsienyje, ypač užsienio medijose, nėra labai teigiamas. Šalis neturi gerai atpažįstamo ženklo. Užsienio spaudos dèmesys dažniausia sutelktas ties mažumų, ekonomikos problemomis ir ekonominiais migrantais, nes šios temos domina skaitytojus. Problemos su mažumomis, smurtu ir ekonomine migracija susijusios su vis dar problemišku Rytų Europos įvaizdžiu, kuris kyla iš XIX ir XX a. pr. įvaizdžio apie Rytų Europą, kaip laukinį, neprognozuojamą ir neišvystytą regioną.

Nepaisant šių neigiamų ịvaizdžio detalių, pozityvi rinkodara apie nacionalinį tapatumą padèjo gerinti šalies įvaizdžio žinomumą ir ji keisti, nors tai ilgalaikis ir sudètingas projektas. Tam, be jokios abejonès, reikia kryptingo valstybès diplomatų, reklamos ir viešųų santykių agentūrų bei įvairių valstybinių institucijų darbo. Rytų Europos šalys lyg ir yra užsièmusios savo nacionalinio įvaizdžio keitimu, siekdamos savo šalis pristatyti kaip modernias, dinamiškas ir turinčias išteklių. Autorẻ daro prielaidą, kad šios kampanijos siekia pakeisti stereotipini šių šalių, kaip neišvystytų ir atsilikusių, įvaizdį. Nauja ịvaizdžio kampanija „Gerų idejjų Slovakija“ (2016) paremta inovatyviomis idejomis ir pateikia Slovakiją kaip šalį, kurioje gyvena protingi ir kūrybingi žmonès. Ši kampanija pristatyta tik prieš metus, bus įdomu stebèti, ar ji padès pakeisti vyraujantị ìvaizdi.

PAGRINDINIAI ŽODŽIAI: Slovakijos ịvaizdis, nacionalinis įvaizdis, Rytų Europa, užsienio spauda.

JEL KLASIFIKACIJA: Z19

Received: 2017.03.23

Revised:2017.04.02

Accepted: 2017.04.07 